DOI https://doi.org/10.18551/rjoas.2018-01.14

\title{
THE DETERMINANTS PERCEPTION OF TAX EVASION ETHICS
}

\author{
Ningsih Devi Nur Cahaya*, Sudarma Made, Baridwan Zaki \\ Faculty of Economics and Business, University of Brawijaya, Indonesia \\ *E-mail: devi nurcahyaningsih@yahoo.com
}

\begin{abstract}
This study aimed to examine the determinants perception of tax evasion ethics, and combined three models based on the research of McGee et al (2012), Lau et al (2013), Lemvora et al (2013). Data collection used survey method on 148 auditors who worked at Public Accountant Office (KAP) Big Ten. The result of this study showed that the justice and taxation systems affect significantly negative toward the perception of tax evasion ethics. Religiosity strengthened the effect of justice, taxation systems, and discrimination on the perception of tax evasion ethics.
\end{abstract}

\section{KEY WORDS}

Perception of ethics, tax evasion, justice, taxation systems, dicrimination, religiosity, materialism.

Tax becomes the source of revenue of Republic of Indonesia to create independence in improving development and growth of economy. In the compilation of state budget (APBN) in 2016, total domestic revenue that came from tax sector is set amounted to $84,96 \%$, an amount of 1.546,7 trillion from total Rp 1.820,5 trillion (Direktorat Penyusunan APBN, 2016). This big contribution requires the government to improve the quality aspects of taxation in Indonesia, in terms of taxation systems as well as the human resources. However, for the past three years, the tax revenue every year always below the target, namely in 2014 only $92 \%$, in 2015 reached $83,3 \%$, and in 2016 was only $84,2 \%$.

Director of Directorate General of Taxes under Ministry of Finance in period 20112014, Fuad Rahmady states that the awareness of Indonesian people to pay the tax were still low, that is corporate taxpayer only $8.7 \%$ and new individual taxpayer $30 \%$ (Wijaya, 2013). Other data showed that the obedient taxpayer only range from $60 \%-70 \%$ and it is dominated by individual taxpayer not corporate taxpayer (Saeroji, 2017). Minister of Finance in 2017, Sri Mulyani states that the ratio of Indonesian tax ranks are lowest in the world that is in the level 10, 3\% (Sukmana, 2017).

Tax evasion often happens in Indonesia. The most loud case in news was Gayus Tambunan (Civil Servant class IIIA, Directorate General of Taxes under Ministry of Finance). Gayus involved in three layers of article, those were corruption, money laundering, and tax evasion. This case has negative impact on some of taxpayers in taxpayer compliance (Rini, 2013). The recent case of tax evasion happened, one of the cases of alleged bribery of tax abolition by PT EK Prima Ekspor Indonesia amounted to Rp 6 millions (Rozie, 2017).

Some of Indonesia's achievement which always low including, the actual revenue from the state tax revenues, tax ratio, and the level of compliance of taxpayers that can indicate the occurrence of tax evasion. Supported with the amount of cases of tax evasion revealed, further strengthening the fact that tax evasion is very widespread in Indonesia. This case cause big question, whether tax evasion is ethical to do? McGee (2016) discusses three views about the tax evasion ethics. Those three ethics namely tax evasion is always unethical, always ethical, and sometimes ethical.

In the study conducted by McGee (2006), tax evasion is considered an ethical action because the lack of justice in the use of money derived from taxes, the high levels of government corruption, and the benefits of tax money are less perceived by the public. Whereas according to Cohn (1998) in McGee et al (2008) based on literature and religious thought, it was revealed that tax evasion always unethical because there is pressure of 
thought that should not underestimate fellow human beings. So, when someone does a tax evasion it will make everyone else look bad and this is a form of disdain for humanity.

McGee et al. (2012) conducted a study on dimentionality scale of tax evasion ethics by survey method around 1100 people in six countries, those are Argentina, Guatemala, Poland, Romania, England, and USA. The result of study found that tax evasion is sometimes ethical, depends on the condition of three dimensions perception ethical scale of items that examined, those are justice, taxation systems, and discrimination. The study with those three variables was also conducted by McGee and Guo (2007), McGee et al. (2008), Nickerson et al. (2009), and McGee et al. (2011). Research sample carried out by McGee et al (2012), limited on the students who already graduated or not graduated yet. Although social research in this decade used many students samples, but McGee considered this thing as limitation in his research, because the samples is considered can or cannot even represent the population as a whole.

In other study, Lau et al. (2013) found another dimension that affect toward perception of tax evasion ethics, that is dimension love of money. In his study, Lau found positive relatonship from love of money on perception of tax evasion ethics and intrinsic religiosity moderates the relationship. Other study that showed the effects love of money on the unethical behaviors carried out by Tang (1992), Tang et al. (2002), Tang and Chiu (2003), Tang et al. (2005), and Elias (2009). The limitation in this study that conducted by Lau et al. (2013) was only used intrinsic and extrinsic religiosity as moderation variables. Lau assumes that there are other variables that can be used, namely materialism. In other study, Lemvora et al. (2013) found the relationship between love of money with materialism. Individual who has materialistic character tend to impress other people (show off), obsessed with high achievement, and considered money is power. These individuals tend to use their money badly and will even act unethical.

This study is a model development of study perceptiop of tax evasion ethics by combining three models based on the previous studies conducted by McGee et al. (2012), Lau et al. (2013), and Lemvora et al. (2013). The research model of McGee et al. (2012) examine the effect of justice, taxation systems, and discrimination on perception of tax evasion ethics. The model study combined with the study of Lau et al. (2013) and Lemvora et al. (2013) that examined the effects love of money on the perception of tax evasion ethics with moderated by religiosity and materialism. Besides, this study develop new model, namely adding moderate variables of religiosity in the effect of justice, taxation systems, and dicrimination toward the perception of tax evasion ethics.

\section{LITERATURE REVIEW}

Perception is a process where individuals organize and interpret their sensory impressions in order to give meaning to the surrounding environment (Robbins, 1996). Perception is an interpretation and an individual's view of something (Muliari \& Setiawan, 2011).

Tax ethics is an action to comply with tax regulations or tax laws that apply, in this case the taxpayer must be routine in paying taxes so that the country's development is done very well (Izza \& Hamzah, 2009). Tax ethics is considered as a regulation that governing individuals in living their lives in the sphere of taxation, how they carry out their tax obligations, whether they have done right, wrong, good or bad (Suminarsasi \& Supriyadi, 2011). From the above explanation, it can be concluded that the tax ethics is a behavior in the sphere of taxation to do taxation obligations properly and correctly.

Basically, tax evasion is a deviant act for violating established rules and can harm others. In other words, tax evasion is unethical act to do. However, based on the stduy of McGee (2006), not everyone considers tax evasion unethical. Tax evasion is also always seen as ethical act to carry out, or sometimes ethical, depending on the conditions that are happening in the surrounding environment. 


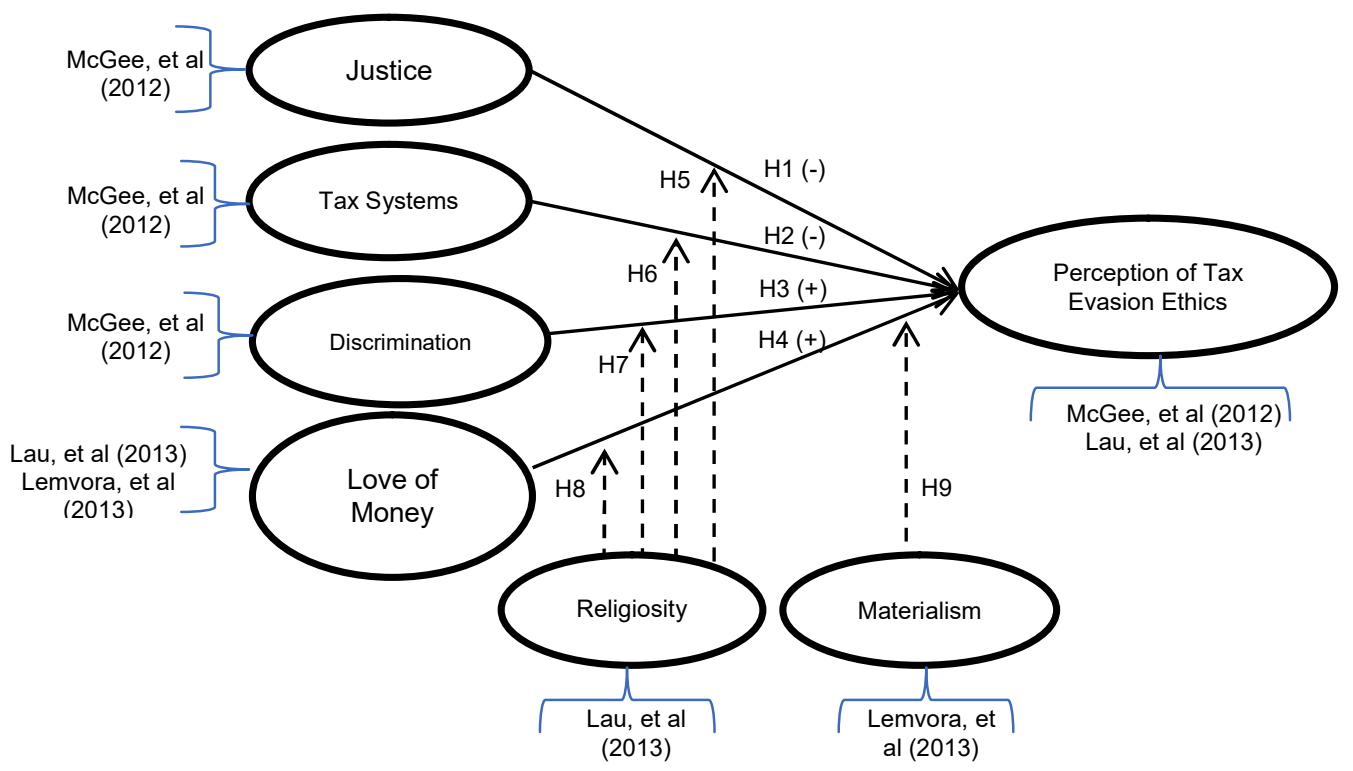

Figure 1 - Research Model (Source: Processed Data, 2017)

According to McGee et al. (2012), justice is a government action that related with the use of tax funds in a positive manner. Suminarsasi and Supriyadi (2011) define justice as a condition in which people should receive equal treatment in taxation and imposition by the state. The government is said to be fair if funds sourced from taxes are used properly. In addition, the treatment of taxation and imposition must be the same, as seen from the tax laws that have been prepared and implemented. Several previous studies have shown that justice negatively affects the perception of tax evasion ethics, that is, the higher the level of justice in the government of a country, then the people will have the perception that tax evasion is an action that is unethical. The study among others was conducted by McGee et al. (2007), McGee \& Guo (2007), McGee et al. (2008), Nickerson et al. (2009), McGee et al. (2011), McGee et al., (2012), and Mukharoroh and Cahyonowati (2014).

H1: Justice negatively influence the perception of tax evasion ethics.

The tax system is defined into the scope of tax rates and the use of tax funds negatively, such as government corruption (McGee et al., 2012). Suminarsasi and Supriyadi (2011) state that the tax system is an existing taxation procedure, related to calculation, payment, and reporting. The tax system is good when it gives convenience to the taxpayer in every procedure. In addition, the tax authorities must play an active role in supervising and carrying out their duties with high integrity. On the contrary, the tax system is not good if the tax authorities cheat when conducting the system, such as corruption. Several previous studies showed that the tax system negatively affects the perception of tax evasion ethics. When the prevailing tax system is good, the public perception about tax evasion is unethical. The research studies were conducted by McGee et al. (2007), McGee \& Guo (2007), McGee et al. (2008), Nickerson et al. (2009), McGee et al. (2011), McGee et al. (2012), Suminarsasi and Supriyadi (2011), and Mukharoroh and Cahyonowati (2014).

H2: The tax system negatively influence the perception of tax evasion ethics.

McGee et al. (2012) explained that discrimination is a different governmental treatment for certain conditions. The government is committed a form of discrimination if the policy applied is only advantageous to certain parties, and on the other hand, the other parties are disadvantaged. According to Suminarsasi and Supriyadi (2011), there are several policies that are considered as a form of discrimination in the taxation in Indonesia, such as the application of zakat to Muslims as a tax deduction and the existence of the Government Regulation No. 46 of 2013 in which the final tax is charged at $1 \%$ of gross income, regardless of whether the business suffered a loss or gain. Several previous studies showed that discrimination positively affects the perception of tax evasion ethics. When the number of discrimination within a country is high, the people will have the perception that the evasion 
of taxes is ethically done. The research studies were conducted by McGee et al. (2007), McGee \& Guo (2007), McGee et al. (2008), Nickerson et al. (2009), McGee et al. (2011), McGee et al., (2012), and Suminarsasi and Supriyadi (2011).

H3: Discrimination positively influence the perception of tax evasion ethics.

Tang (1992) explained that love for money is a measure of one's subjective feelings toward money. Individuals with high love for money are ethically less sensitive than people who have low love for money (Tang, 2002). Several previous research studies showed that love for money positively affects the perception of tax evasion ethics. When a person's feeling of love for money is higher, then everything will be done to meet his needs including the tax evasion. The research studies were conducted by Tang (1992), Tang et al. (2002), Tang and Chiu (2003), Tang et al. (2005), Elias (2009), Lemvora et al. (2013), and Lau et al. (2013).

H4: The love for money positively influence the perception of tax evasion ethics.

Glock and Stark (1968) in Ancok \& Nashori (2001) defined religiosity as a system of symbols, belief systems, value systems, and behavioural systems centred on deeply understood and meaningful issues. Glock and Stark (1968) in Repstad \& Furseth (2006) stated that there are five dimensions in religiosity, namely the belief, religious practice, the experience, the knowledge, and the consequential. Individuals with high religiosity will be more objective in assessing the justice applied by the government. The individual will be able to distinguish objectively between right and wrong, as well as fair and unfair, based on the internalized religious values within himself. The higher the religiosity of a person, followed by a government that has applied justice, the further the increase of public confidence in the government. This makes the public assume that tax evasion is increasingly unethical to do.

H5: Religiosity strengthens the negative influence of justice on the perception of tax evasion ethics.

Individuals with high religiosity will be more objective in assessing the prevailing taxation system. The individual will be able to distinguish objectively between the right and wrong things in the tax system, based on the internalized religious values within himself. The higher the religiosity of a person, followed by a good taxation system and the easy process of taxation implementation, the further the increase of the satisfaction of the community in settling its tax obligations. This makes the public assume that tax evasion is increasingly unethical to do.

H6: Religiosity strengthens the negative influence of the tax system on the perception of tax evasion ethics.

Individuals with high religiosity will be more objective in assessing the treatment of government discrimination. They will be able to distinguish objectively whether the people's attitudes or the government policy contains the elements of discrimination or not, whether there are some disadvantaged parties and other parties who benefit, based on the values of religion internalized in him. The high religiosity can reinforce the positive relationship between discrimination and the perception of tax evasion ethics. People will assume that the tax evasion is more ethical to do to get the things that become the rights within each individual.

H7: Religiosity strengthens the positive influence of discrimination on the perception of tax evasion ethics.

Religiosity moderates the positive relationship of love for money to the perception of tax evasion ethics. Several previous studies showed that religiosity moderates the positive relationship of money for love to the perception of tax evasion ethics. The higher the religiosity will lower one's love for money, and tax evasion increasingly unethical to do. The research studies were conducted by Lau et al. (2013), Rosianti \& Mangoting (2014), and Hafizhah (2016).

H8: Religiosity weakens the positive influence of money for love on the perception of tax evasion ethics.

Richins (2004) stated that materialism is a person's attitude by prioritizing success, centrality, and happiness. In the context of success, the materialist will judge his and other 
success by using a measure of the quantity and quality of what they have. In the context of centrality, materialists place the ownership and acquire all possessions in their lives. While in the context of happiness, the materialists will recognize that ownership is essential to satisfaction and well-being in their lives. Several previous studies showed that materialism moderates the positive relationship of love for money on the perception of tax evasion ethics. High materialism will increase one's love for money, and tax evasion is more ethical to do. The study was conducted by Lemvora et al. (2013).

H9: Materialism strengthens the positive influence of love for money on the perception of tax evasion ethics.

\section{METHODS OF RESEARCH}

The population in this study was external auditors' works in Big Ten, a Public Accounting Firm (KAP). Sample selection was done using convenience sampling method. In this study, the population was not known with certainty and the sampling technique used according to Abdillah and Hartono (2015) was at least 10 times of the number of hypotheses prepared. The hypotheses of this research were 9 hypotheses so that the minimum sample amount was 90 samples. The researchers determined the sample used twice the minimum sample, which were 180 samples divided equally into 10 Big Ten KAP. Thus, in a KAP 18 auditors will be taken as a sample.

This research used a computer-delivered survey technique in collecting the data, which was done by the internet (Hartono, 2015). Then, it was processed using Partial Least Square (PLS) statistical test tools with version 2.0 M3 SmartPLS ver software. The indicators of justice variables, taxation systems, and discrimination were based on the concept of Nickerson et al. (2009), McGee et al. (2012), and Suminarsasi and Supriyadi (2011). The variable of love for money was measured using Money Ethic Scale (MES) developed by Tang (2002) and adopted by Lau et al. (2013). Religiosity moderation variables used Glock and Stark indicator (1968) in Repstad \& Furseth (2006). The materialist variable was based on the concept of Lemvora et al. (2013). Variable perceptions of tax evasion ethics were based on the concept of McGee et al. (2012) and Suminarsasi and Supriyadi (2011). The respondents will be asked to provide an approval response on a scale of 1 for strongly disagree up to 7 for strongly agree.

\section{RESULTS AND DISCUSSION}

The number of questionnaires distributed by the researchers was 180 questionnaires. The number of questionnaires that was not returned was 32 questionnaires and had been done reconfirmation stage for three times. Total questionnaires returned of 148 were processed entirely. Based on the survey results, the majority of respondents were male $(54 \%)$ with age of $20-30$ years $(97 \%)$. The majority of respondent positions were junior auditors (58\%) with length of working in KAP for $1-2$ years $(59 \%)$. The last education of majority of respondents were S1 (94\%) and the education sector was accounting $(100 \%)$.

The loading factor value of all constructs was more than 0.7, while the Average Variance Extracted (AVE) value and the communality value was more than 0.5 . In addition, the AVE root value was more than the correlation of latent variables. The value of Cronbach's Alpha was above 0.6 and the value of Composite Reliability was above 0.7. Therefore, it can be concluded that all indicators in the instrument of this study was valid and reliable, so the hypothesis testing can be done.

The value of $R^{2}$ from the construct of this research was 0.6917 . The value explained that variations in the change of perceptual constructs of tax evasion ethics can be explained by $69.17 \%$ by the construct of justice, taxation system, discrimination, and love for money, as well as the moderating constructs of religiosity and materialism. While the remaining $30.83 \%$ was explained by the other constructs outside this research model. 
Table 1 - The Results of Main Hypothesis Testing

\begin{tabular}{|c|c|c|c|c|}
\hline Hypothesis & Construct & Original Sample & T- Statistic & Result \\
\hline $\mathrm{H} 1$ & Justice -> Perception of Tax Evasion Ethics & $-0,1418$ & 4,7398 & Accepted \\
\hline $\mathrm{H} 2$ & Taxation System -> Perception of Tax Evasion Ethics & $-0,0927$ & 2,0647 & Accepted \\
\hline H3 & Discrimination -> Perception of Tax Evasion Ethics & 0,5740 & 17,6499 & Accepted \\
\hline $\mathrm{H} 4$ & Love for Money -> Perception of Tax Evasion Ethics & 0,0904 & 2,5881 & Accepted \\
\hline H5 & Justice*Religiosity -> Perception of Tax Evasion Ethics & $-0,0704$ & 1,7874 & Accepted \\
\hline $\mathrm{H} 6$ & Taxation SystemReligiosity -> Perception of Tax Evasion Ethics & 0,9423 & 10,4490 & Accepted \\
\hline $\mathrm{H} 7$ & Discrimination*Religiosity -> Perception of Tax Evasion Ethics & 0,9219 & 15,9367 & Accepted \\
\hline H8 & Love of MoneyReligiosity -> Perception of Tax Evasion Ethics & $-0,2666$ & 1,7303 & Accepted \\
\hline $\mathrm{H} 9$ & Love of Money*Materialism -> Perception of Tax Evasion Ethics & 0,3066 & 4,7655 & Accepted \\
\hline
\end{tabular}

Source: Primary Data Processed (2017).

Table 2 - Comparison between Value of Total Effect without Moderation Effect and Value of Total Effect with Moderation Effect

\begin{tabular}{cccc}
\hline $\begin{array}{c}\text { Hypothesis without } \\
\text { Moderation Effect }\end{array}$ & Original Sample & $\begin{array}{c}\text { Hypothesis with } \\
\text { Moderation Effect }\end{array}$ & Original Sample \\
\hline H1 & $-0,1418$ & H5 & $-0,0704$ \\
H2 & $-0,0927$ & H6 & 0,9423 \\
H3 & 0,5740 & H7 & 0,9219 \\
H4 & 0,0904 & H8 & $-0,2666$ \\
H4 & 0,0904 & H9 & Strengthen \\
Weaken & Sthen \\
\hline
\end{tabular}

Source: Primary Data Processed (2017).

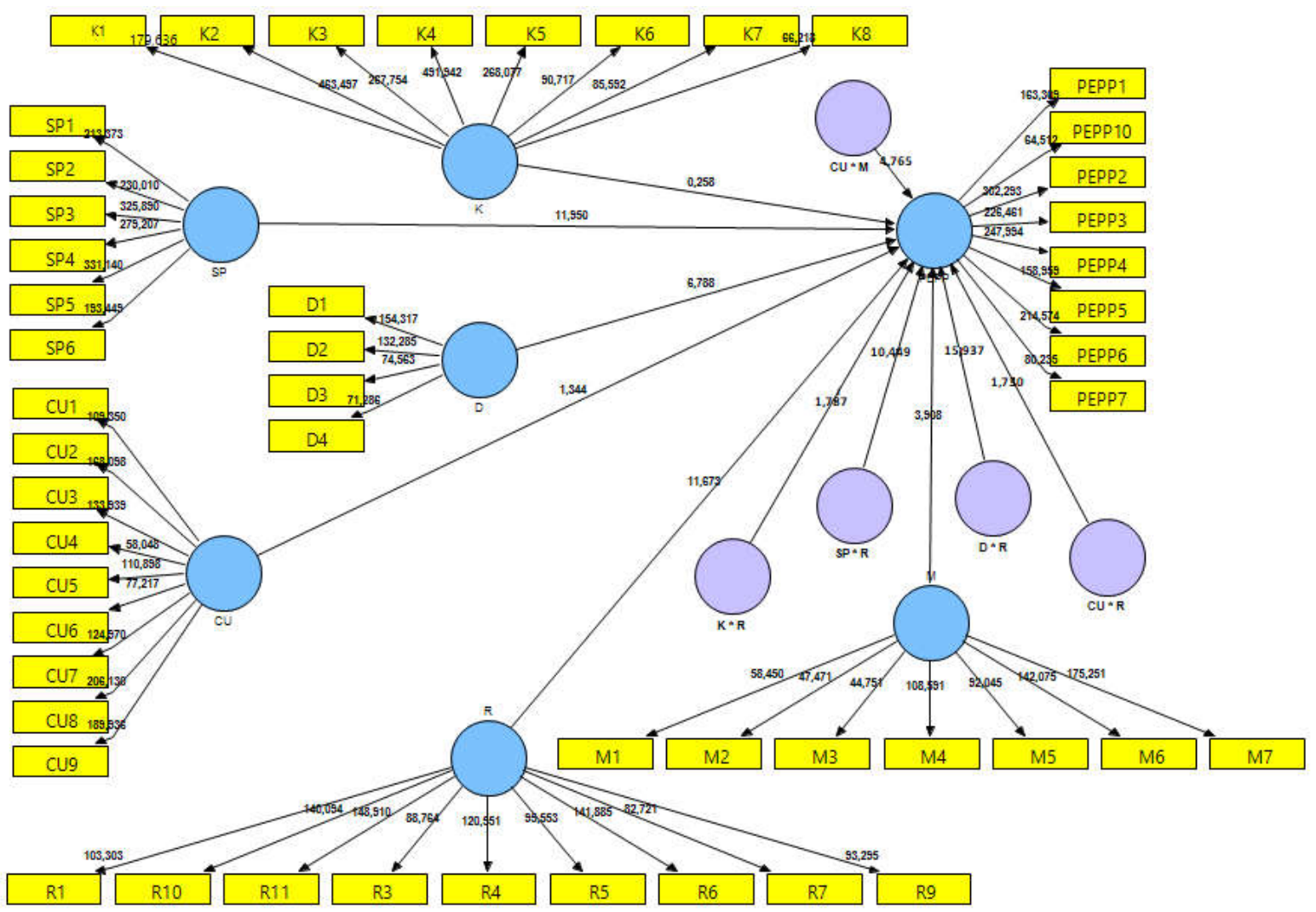

Figure 2 - Structural Model of Moderation Influence Hypothesis Testing

(Source: Processed Primary Data, 2017)

Justice has a negative effect to the perception of tax evasion ethics. The higher applicability of justice in a country, the auditor's perception on tax evasion which considered ethical is getting lower. This result is consistent with various study from McGee et al. (2007), McGee \& Guo (2007), McGee et al. (2008), Nickerson et al. (2009), McGee et al. (2011), McGee et al. (2012), and Mukharoroh and Cahyonowati (2014). A fair application of justice in a country will be perceived by its community. Low tax rates, wise usage of tax funds, and 
justice in preparation and application of tax laws will boost public confidence to the government so it will increase public's sense of trust and security to pay their taxes. Public will entrust the management of taxes to the government. Thus, public will assume that tax evasion which violates the laws and harms the public is an unethical action.

Tax system has a negative impact to the perception of tax evasion ethics. The better the tax system application, the auditor's perception of tax evasion which is considered ethical will be lower. This result is consistent with the study of McGee et al. (2007), McGee \& Guo (2007), McGee et al. (2008), Nickerson et al. (2009), McGee et al. (2011), McGee et al. (2012), Suminarsasi and Supriyadi (2011), and Mukharoroh and Cahyonowati (2014). Good tax system will provide convenience for the public to fulfill their tax obligations as well as if it's supported by a good human resources or tax officers. This condition will give a high confidence to the public as taxpayers. A good tax system, wise management of tax funds, competent and non-corrupt tax officers, and uncomplicated tax payment procedure will increase public trust to the tax officers and encourage public to pay their taxes. It will affect the auditor's perception that tax evasion is unethical thing to do.

Discrimination positively affects the perception of tax evasion ethics. The more discriminatory forms exist in the applicable tax regulations, the bigger auditors' perception that tax evasion is an ethical action to do. This is consistent with the study of McGee et al. (2007), McGee \& Guo (2007), McGee et al. (2008), Nickerson et al. (2009), McGee et al. (2011), McGee et al. (2012), and Suminarsasi and Supriyadi (2011). Based on the statements from the questionnaire it appears that discriminations are exemptions in taxes. In tax regulations, government provides different treatment to various circles of community. It is regarded as a form of discrimination because it only benefits certain groups in society. If tax regulations are disadvantageous to some groups, especially the lower middle class, thus public confidence to the government will decrease. It will form a perception that tax evasion is an ethical thing to do or tax evasion may be conducted to cover the loss.

Money love has positive effect to the perception of tax evasion ethics. The higher a person's love for money, it means the higher his perception of tax evasion is an ethical thing. This is consistent with the study of Tang (1992), Tang et al. (2002), Tang dan Chiu (2003), Tang et al. (2005), Elias (2009), Lemvora et al. (2013) dan Lau et al. (2013). The more a person's love for money, the more likely this person will have a huge interest in money and tend to do everything to meet his needs for money despite having to commit unethical acts and harming other people, such as through tax evasion.

Religiosity strengthens the influence of justice, tax system, and discrimination against the perception of tax evasion ethics. However, religiosity weakens the influence of money love to the perception of tax evasion ethics. Glok and Stark (1968) in Repstad \& Furseth (2006) states that there are five dimensions of religiosity, which is the belief, religious practice, the experience, the knowledge and the consequential. Perspectives of various religions are equal. It all has an average assumption that tax evasion is unethical when the tax system and justice is fulfilled. Individuals with religious orientation perceive that money is not everything to meet the needs. Individuals with high religiosity will relate their needs to the motivations and religious meanings they believe in. Ismail (2012) explains that individuals live according to their religion will have a religious orientation. These individuals will keep their commitment to their religion unconditionally and make decisions independently. Religion or faith is perceived as an inherent need in every action and considered as the most essential part.

Individuals with high religiosity will be more objective in assessing the application of justice by the government and the prevailing tax system. These individuals may able to objectively differentiate between the right or wrong, justice or injustice, based on the religious values internalized within them. The more religious of a person, followed by justice implementation, good tax system, and good facilitation of tax process by the government, it will increase public confidence in the government performance and increase public satisfaction in fulfilling their tax obligations. This will make public's perception of tax evasion is unethical to do. Moreover, individuals with high religiosity will be more objective in assessing the government discrimination. These individuals will be able to whether the 
government attitude or policy contains elements of discrimination or not, whether there are some disadvantaged groups or others who gain benefits from it, based on religion values internalized within them. This will make public think that tax evasion is an ethical thing to do to gain each individual's rights. However, high religiosity will degrade someone's love for money and decrease someone's desire to conduct tax evasion, or assume that tax evasion is unethical. This result is consistent with the study of Lau et al. (2013), Rosianti \& Mangoting (2014), and Hafizhah (2016).

Materialism strengthens the positive influence of money love to the perception of tax evasion ethics. The more someone's love for money accompanied by high materialism, the more perception that tax evasion is ethical to do. This result is consistent with the study of Lemvora et al. (2013). Materialistic individuals tend to have high level of luxury and expensive goods consumption (Trojsi et al., 2016), and unable to make a saving (Christopher et al., 2004). According to Garðarsdottir \& Dittmar (2012), materialistic individuals tend to have a bad skill of managing money and a high level of consumption, and also followed by a high amount of debt. Materialistic individuals tend to desire a lot of money to buy all the luxury goods as a way to show off their identity. Individuals with high materialism tend to have a high consumption of expensive and luxury goods, have a poor management of money, and use money as a means to meet the needs and self-acclaimed in society, such as satisfaction, success, centrality, and happiness. High materialism will increase someone's love of money, leading to increase someone's desire to commit tax evasion, or perceives that tax evasion is ethical to do.

\section{CONCLUSION}

This research aims to examine the influence of justice, tax system, discrimination and loving money toward ethic perceptions of tax evasion by being moderated by religiosity and materialism. Survey process is conducted by sending questioner by email to 148 external auditors who work in KAP Big Ten. This research uses three models which refer to the research of McGee et al. (2012), Lau et al. (2013), and Lemvora et al. (2013). this research also develops new model, which is the moderating variable of religiosity in the influence of justice tax system and discrimination toward tax evasion ethics. The result of the research supports those three models.

The result of the research proves that the more justice implementation and tax system in a country, it will increase society trust to government, so that tax evasion that breaks the rule and harms society is not ethical to do. Other than that, the government's policy that has discrimination constituent will decrease society trust toward government, so that it will establish perception that tax evasion is the right thing to do. The high love feeling toward money will also make individual does anything to fulfill his/her needs about money, including tax evasion and the action is considered ethic to do.

Religiosity strengthens the influence of justice, tax system and discrimination toward ethic perception of tax evasion. However, it weakens the influence of loving money toward ethic perception of tax evasion. High religiosity in individual that based on religion values which are internalized in him/her will be more objective in valuing good and righ things. Individual is objective in valuing justice which applied properly by the government and tax system which ease people. So that tax evasion is considered as unethical to do. Other than that, individual with high religiosity is also more objective valuing government's policy that has discrimination constituent and harms one of parties, so that tax evasion is considered ethical to do to get the right of individual. However, high religiosity will decrease the feeling of loving money, so that it is considered unethical to do. In this case, high materialism will increase the feeling of loving money to individual, so that tax evasion is considered as an ethical to do. 


\section{REFFERENCES}

1. Abdillah, W., \& Hartono, J. (2015). Partial Least Square: Alternatif Structural Equation Modeling (SEM) dalam Penelitian Bisnis. Yogyakarta: Penerbit ANDI.

2. Ancok, D., \& Nashori, S. (2001). Psikologi islami: Solusi islam atas problem-problem psikologi. Yogyakarta: Pustaka Pelajar.

3. Christopher, A. N., Marek, P., \& Carroll, S. M. (2004). Materialism and attitudes toward money: An exploratory investigation. Individual Differences Research, 2(2), 109-117.

4. Direktorat Penyusunan APBN. (2016). Anggaran Pendapatan dan Belanja Negara Tahun 2016. Dipetik Juni 1, 2017, dari http://www.kemenkeu.go.id/en/node/47651

5. Elias, R. Z. (2009). The Relationship Between Accounting Students, Love of Money and Their Ethical Perception. Managerial Auditing Journal, 25(3).

6. Garðarsdottir, R. B., \& Dittmar, H. (2012). The relationship of materialism to debt and financial well-being: The case of Iceland's perceived prosperity. Journal of Economic Psychology, 33, 471-481.

7. Hafizhah, I. (2016). Pengaruh Etika Uang (Money Ethics) Terhadap Kecurangan Pajak (Tax Evasion) dengan Religiusitas, Gender, dan Materialisme sebagai Variabel Moderasi. JOM FEKON, 3(1).

8. Hartono, J. (2015). Metodologi Penelitian Bisnis: Edisi 6. Yogyakarta: BPFE.

9. Izza, I. A., \& Hamzah, A. (2009). Etika Penggelapan Pajak Perspektif Agama: Sebuah Studi Interpretatif. Simposium Nasional Akuntansi, (hal. Volume 12). Palembang.

10. Lau, T. C., Choe, K. L., \& Tan, L. P. (2013). The Moderating Effect Of Religiosity In The Relationship Between Money Ethics And Tax Evasion. Asian Social Science, 9(11).

11. Lemvora, S., Reiterova, E., Fatenova, R., Lemr, K., \& Tang, T. L.-P. (2013). Money is Power: Monetary Intelligence: Love of Money and Temptation of Materialism Among Czech University Students. Journal Business Ethics.

12. McGee, R. W. (2006). Three Views on The Ethics of Tax Evasion. Journal of Business Ethics, 67: 15-35.

13. McGee, R. W., \& Guo, Z. (2007). A survey of law, business and philosophy students in China on the ethics of tax evasion. Society and Business Review, 2(3), 299-315.

14. McGee, R. W., Benk, S., Yildirim, H., \& Kayikci, M. (2011). The Ethics of Tax Evasion: A Study of Turkish Tax Practitioner Opinion. European Journal of Social Sciences , 18, 3.

15. McGee, R., Nickerson, I., \& Pleshko, L. P. (2008). A Comparative Study Of Tax Evasion In Six Countries. Academy of Legal, Ethical and Regulatory Issues, 12(1), 25-30.

16. McGee, R., Nickerson, I., Pleshko, L., \& Broihahn, M. (2012). The Ethics Of Tax Evasion: An Investigation Into Demographic Differences. Journal of Legal, Ethical and Regulatory Issues, 15(1), 105-117.

17. McGee, R., Palau, S. L., \& Jaramillo, F. J. (2007). The Ethics Of Tax Evasion: An Empirical Study Of Ecuador. Andreas School of Business Working Paper, Barry University.

18. Mukharoroh, A. H., \& Cahyonowati, N. (2014). Analisis Faktor-Faktor Yang Mempengaruhi Persepsi Wajib Pajak Mengenai Penggelapan Pajak. Diponegoro Journal Of Accounting, 3(3), 1-7.

19. Muliari, N. K., \& Setiawan, P. E. (2011). Pengaruh Persepsi Tentang Sanksi Perpajakan Dan Kesadaran Wajib Pajak Pada Kepatuhan Pelaporan Wajib Pajak Orang Pribadi Di Kantor Pelayanan Pajak Pratama Denpasar Timur. Jurnal Ilmiah Akuntansi dan Bisnis, $6,1$.

20. Nickerson, I., Pleshko, L., \& McGee, R. W. (2009). Presenting The Dimensionality Of An Ethics Scale Pertaining To Tax Evasion. Journal of Legal, Ethical and Regulatory Issues, 12(1), 1-14.

21. Repstad, \& Furseth, I. (2006). An introduction to the sociology of religion classical and contemporary perspectives. Burlington: Ashgate Publishing Company.

22. Richins, M. L. (2004). The material values scale: Measurement properties and development of a short form. Journal of Consumer Research, 31(1), 209-219. 
23. Rini. (2013). Kasus Gayus Tambunan Pengaruhi Kepercayaan Wajib Pajak. Dipetik Juli 7, 2017, dari http://www.republika.co.id/berita/ekonomi/makro/13/10/01/mtzen4-kasusgayus-tambunan-pengaruhi-kepercayaan-wajib-pajak

24. Robbins, S. P. (1996). Perilaku Organisasi, Konsep, Kontroversi dan Aplikasi, Alih Bahasa: Hadyana Pujaatmaka, Edisi Keenam. Jakarta: PT. Bhuana IImu Populer.

25. Rosianti, C., \& Mangoting, Y. (2014). Pengaruh Money Ethics terhadap Tax Evasion dengan Intrinsic dan Extrinsic Religiosity sebagai Variabel Moderating. Tax \& Accounting Review, 4(1).

26. Rozie, F. (2017). Terdakwa Kasus Suap Pajak Akui Teman Lama Adik Ipar Jokowi. Dipetik Juli 7, 2017, dari http://news.liputan6.com/read/2863538/terdakwa-kasus-suappajak-akui-teman-lama-adik-ipar-jokowi

27. Saeroji, O. (2017). Menakar Kadar Kepatuhan Wajib Pajak. Dipetik Juni 1, 2017, dari http://www.pajak.go.id/content/article/menakar-kadar-kepatuhan-wajib-pajak

28. Sukmana, Y. (2017). Rasio Pajak Masih Rendah, Sri Mulyani Heran. Dipetik Agustus 11, 2017, dari http://ekonomi.kompas.com/read/2017/07/12/191629826/rasio-pajak-masihrendah-sri-mulyani-heran

29. Suminarsasi, W., \& Supriyadi. (2011). Pengaruh Keadilan, Sistem Perpajakan, dan Diskriminasi Terhadap Persepsi Wajib Pajak Mengenai Etika Penggelapan Pajak (Tax Evasion). Tesis, Jurusan Akuntansi Magister Sains Fakultas Ekonomika dan Bisnis Universitas Gajahmada Yogyakarta.

30. Tang, T. (1992). The Meaning of Money Revisited. Journal of Organizational Behavior, 13, 197-202.

31. Tang, T. L.-P., Chiu, R. K., Akande, A., Alzubaidi, A. S., Borg, M. G., Cheng, B., et al. (2002). Is The Love Of Money The Root Of All Evil? Or Different Strokes For Different Folks: Lessons In 12 Countries. Paper presented to the International Conference on Business Ethics in the Knowledge Economy, Hong Kong.

32. Tang, T., \& Chiu, R. (2003). Income, Money Ethics, Pay Satisfaction, Commitment, And Unethical Behavior: Is The Love Of Money The Root Of Evil For Hong Kong Employees? Journal of Business Ethics, 46, 13-30.

33. Tang, T., Tang, D., \& Luna-Arocas, R. (2005). Money Profiles: The Love Of Money, Attitudes, And Needs. Personnel Review, 34(5), 603-618.

34. Trojsi, J. D., Christopher, A. N., \& Marek, P. (2006). Materialism and money spending disposition as predictors of economic and personality variables. North American Journal of Psychology, 8(3), 421-436.

35. Wijaya, A. S. (2013). Kesadaran Bayar Pajak Warga Masih Rendah. Dipetik Juli 16, 2017, dari http://www.tempo.co/read/news/2013/09/23/092515799/Kesadaran-BayarPajak-Warga-Masih-Rendah

\section{APPENDIX - QUESTIONNAIRE}

Justice

1. Tax evasion is ethical, even though the fee is low.

2. Tax evasion is ethical, even though tax fund is used right and well.

3. Tax evasion is ethical, even though tax fund is used to build important public facility.

4. Tax evasion is ethical, if tax fund is used for activities that do not give profit for me.

5. Tax evasion is ethical, even though tax fund is used for activites that give profit for me.

6. Tax evasion is ethical, if a person has high income, he has to pay tax in high rate.

7. Tax evasion is ethical, if government is not fair in organizing the tax law.

8. Tax evasion is ethical, if tax officer is not fair in applying tax regulation.

\section{TAX SYSTEM}

1. Tax evasion is ethical, if tax rate is high and it is not suitable with the income.

2. Tax evasion is ethical, if tax system is not fair.

3. Tax evasion is ethical, if tax money that is collected is not maintained wisely.

4. Tax evasion is ethical, if tax fund source is from politicians who are corruption.

5. Tax evasion is ethical, if the procedure of paying tax complicates.

6. Tax evasion is ethical, if Directorate General of Taxation (DJP) does not give good socialization to ease taxes payment. 


\section{DISCRIMINATION}

1. Tax evasion is considered ethical, if government does discrimination about religion, race and culture background.

2. Tax evasion is considered ethical, if government imprisons people because of politic opinion.

3. Tax evasion in considered ethical if zakat for Islam is used as tax deduction factor.

4. tax rate for business with turnover under 4,8 Billion is charged gross circulation, whereas for turnover over 4,8 billion is charged of profit. It is discrimination for small and medium enterprises.

\section{LOVE MONEY}

1. Money is good and worth it.

2. Money is important factor and interesting in my life.

3. Money represents my achievement, success and accomplishment.

4. Money distinguishes me to other people.

5. I am motivated to hard work because of money.

6. Money is my motivator.

7. Having much money is good.

8. I want to be wealthy.

9. My life is delight if $i$ am wealthy and have much money.

\section{RELIGIONITY}

1. I believe to one God.

2. There are many mountains are evidences that God exist.

3. I believe that Scripture teaches ketauhidan, even though I have never read that.

4. I believe that fasting healthy.

5. I will always pray in good or bad situation because with the prayer I feel there is better change.

6. I pray regularly.

7. I feel that breath is God's love for His creatures.

8. I am afraid to God.

9. I am happy seeing other people follow their religion.

10. I always keep myself from unlawful income

11. I always try to avoid little or big sin.

12. I always help people who need me.

13. I tend to be honest, fair and not disgrace other people.

14. I will prevent actions that harm other people.

\section{MATERIALISM}

1. I am amazed with person who has luxury house, car and cloth.

2. My life is represented by things I have.

3. I like to have things that make people amazed.

4. I keep simple life after fulfilling my needs.

5. I buy things that make me happy.

6. I like luxury in my life.

7. My life is better if I have things that I haven't got before.

8. I am happier id I am able to buy many things.

9. Sometimes I am sad if I am not able to buy things I like.

\section{ETHICAL PERCEPTION OF TAX EVASION}

1. Tax evasion is ethical if tax rate is too high.

2. Tax evasion is ethical if tax money is not used to fund general state expenditure.

3. Tax evasion is ethical if $i$ feel benefit from tax money.

4. Tax evasion is ethical because weak law.

5. Tax evasion is ethical if there is discrimination in tax.

6. Tax evasion is ethical if government is corruption.

7. Tax evasion is ethical if government is not transparent in establishing tax money.

8. Tax evasion is ethical if people with the same high income has to pay the same rate.

9. Tax evasion is ethical even though tax fund is used to a moral project.

10. Tax evasion is ethical if all people do tax evasion.

11. Tax evasion is ethical if taxpayer is not able to pay. 